\title{
Anna Czelakowska, 2010, Opisy fleksyjne w gramatykach polskich lat 1817-1939, Kraków: Wydawnictwo Naukowe „Księgarnia Akademicka”
}

Opis ewolucji polskiej wiedzy językoznawczej ma jak dotąd dość bogatą literaturę, jednak - o ile tematyka z zakresu składni, fonetyki i słowotwórstwa doczekała się obszernych monograficznych opracowań, o tyle dzieje nauki o wyrazie, a w tym wypadku: ewolucji opisów gramatycznych, z rzadka stanowiły temat dla całościowego studium, zwłaszcza w oparciu o tak bogaty materiał badawczy1. Wyznaczone przez Annę Czelakowską ramy czasowe dla monograficznego opracowania historii opisów fleksyjnych w literaturze przedmiotu korespondują z dotykającymi rozwoju myśli językoznawczej pracami Jerzego Podrackiego (1982) i Mirosława Skarżyńskiego (1994, 2001)², dzięki czemu książka stanowi dopełnienie i pogłębienie wskazanej tematyki.

Sformułowaniu wniosków posłużyła autorce analiza ponad 40 gramatyk języka polskiego w przedstawionym $\mathrm{w}$ tytule pracy przedziale czasowym. Granicą początkową dla badanego materiału jest Gramatyka języka pol-

1 Ogólne kwestie rozwoju kategorii gramatycznych i podziałów fleksyjnych, jak również wzmianki $\mathrm{w}$ monograficznych opracowaniach poszczególnych gramatyk języka polskiego były tematem wielu prac, m.in.: S. Szlifersztejnowej (1969, Kategoria strony. (Z historii myśli lingwistycznej), Wrocław: Zakład Narodowy im. Ossolińskich), M. Skarżyńskiego (1994, Części mowy i ich kategorie $w$ gramatykach polskich XIX i XX wieku (1817-1938), Kraków: Wydawnictwo Uniwersytetu Jagiellońskiego; 2001, $W$ kręgu gramatyk polskich XIX $i$ XX wieku, Kraków: Historia Iagiellonica), J. Podrackiego (1982, Koncepcje składniowe $w$ gramatykach języka polskiego (rys historyczny), Warszawa: Wydawnictwo Uniwersytetu Warszawskiego), M. Basaja (1986, W poszukiwaniu tradycji. Zasady gramatyki Onufrego Kopczyńskiego, w: M. Basaj (red.), Typy opisów gramatycznych języka. Materiały polsko-czeskiej sesji naukowej, Jabłonna 15-17 XI 1983, Wrocław: Zakład Narodowy im. Ossolińskich, s. 199-206).

2 Zob. przyp. 1. 
skiego Onufrego Kopczyńskiego, tzw. pozgonna (1817), końcową natomiast - Gramatyka współczesnej polszczyzny kulturalnej w zarysie Zenona Klemensiewicza (1939). Warto zwrócić uwagę, że analizowana tu tradycja gramatyczna nie bazuje wyłącznie na wskazanym wyżej materiale, autorka sięga niejednokrotnie do licznych artykułów i monografii z tego okresu, a same ramy czasowe nie stanowią również ścisłego ograniczenia, by nie krępować w wysuwaniu ogólnych wniosków na tle porównawczym. A. Czelakowska odwołuje się zatem do wcześniejszych prac przedstawiających koncepcje lingwistyczne, m.in. gramatyk O. Kopczyńskiego sprzed 1817 r., W. Szylarskiego, T. Szumskiego, P. Stojeńskiego, F. Menińskiego, jak i późniejszych.

Autorka stara się omówić wszystkie funkcjonujące w literaturze przedmiotu danego okresu równolegle rozwijające się i konkurujące ze sobą poglądy i metodologie w aspekcie opisowym, co z kolei daje możliwość przedstawienia ich w perspektywie historycznego rozwoju, będącego skutkiem zmian w pojmowaniu przez językoznawców omawianej problematyki w wyniku ewolucji narzędzi i materiału analiz, wskazując zarówno nurt główny, jak i kierunki poboczne owego procesu.

Praca składa się z pięciu rozdziałów, otwiera ją wstęp, zamykają: zakończenie, bibliografia i indeks osób. Opis kształtowania się nauki o fleksji skupiony jest wokół kilku podstawowych aspektów tego tematu, czemu ściśle odpowiada układ kompozycyjny książki. W dwu początkowych rozdziałach przedstawia autorka historyczne tło dotyczące zmian w opisie języka, co następnie ogranicza do rozważań z zakresu kształtowania się podstawowych pojęć i metodologii w odniesieniu do morfologii i ściślej: fleksji. Przedstawia zatem periodyzację dziejów polskiej myśli językoznawczej z podstawową drogą jej ewolucji od historyczno-porównawczej do podejścia ściśle synchronicznego, zwracając szczególną uwagę na współistnienie pierwiastka normatywności i opisowości oraz stopniową zmianę ich relacji. Stara się określić, jak wobec analizowanego materiału kształtowało się pojęcie nauki o wyrazie i jej miejsce w opisie gramatycznym języka, następnie - wydzielenie się w jej obrębie fleksji. Określa powolne kształtowanie się zakresu fleksji i podejście różnych badaczy języka do kwestii problematycznych, takich jak zakwalifikowanie działu o nieodmiennych częściach mowy, alternacji głoskowych w rdzeniach i tematach obocznych, kwalifikacji poszczególnych kategorii gramatycznych jako fleksyjne i niefleksyjne. 
W rozdz. III autorka skupia się na przedstawieniu kształtowania się rozumienia podstawowych dla jej rozważań pojęć: wyrazu, formy wyrazowej, kategorii gramatycznych oraz części mowy, następnie na opisie budowy wyrazu. Wskazuje na często spotykany we wcześniejszych pracach gramatykopisarzy (ale także i w tych XX-wiecznych) problem braku definiowania podstawowych terminów lub stosowanie definicji ostensywnych, głównie w odniesieniu do pojęcia wyraz. Oprócz rzetelnego przedstawienia ewolucji w rozumieniu tego terminu zwraca także uwagę na jego rozumienie rzeczywiste, niekiedy nie do końca przystające do proponowanych definicji w okresie amatorskim i stopniowe uściślanie pojęć w okresie naukowym. Ów okres - podobnie jak w poprzednim rozdziale - omówiła autorka, opisując podstawowe założenia ważniejszych prac XX stulecia, od gramatyki szkolnej I. Steina i R. Zawilińskiego (1907) po rozprawę Z. Klemensiewicza (1939).

Kolejne dwa obszerne rozdziały: Granice paradygmatów oraz Podziały i opisy fleksyjne stanowią główny trzon, a zarazem najciekawszą część, rozprawy. W rozdz. IV autorka omawia zakres paradygmatu fleksyjnego wyrazów uznanych przez dawnych gramatykopisarzy za odmienne, czyli rzeczownika, przymiotnika i przysłówka oraz czasownika. Wskazuje tu też na podstawowy problem w rozróżnieniu kategorii fleksyjnych i niefleksyjnych w odniesieniu do słowotwórstwa i składni, czego przejawem było np. uznawanie przysłówka za wyraz odmienny (stopniowanie, ale też przez przypadki!), przypisanie rzeczownikom możliwości stopniowania lub odmiany przez rodzaje itp. Dla czasownika szczegółowo omawia, jak w XIX- i XX-wiecznych gramatykach rozumiano podstawowe kategorie: najpierw stronę $\mathrm{i}$ aspekt, następnie formy koniugacyjne: czas, tryb, a także liczne konstrukcje składniowe włączane ówcześnie do paradygmatu czasownika - imiesłowy (wg niektórych gramatyk wyróżniono ich nawet kilkanaście, do ok. 20) i gerundium. W rozdz. V A. Czelakowska skupia się na opisach i podziałach deklinacji rzeczownika, przymiotnika, zaimka, liczebnika oraz koniugacji, wskazując założenia poszczególnych autorów gramatyk oraz sposoby ich realizacji. Jej opis ma więc charakter krytycznej syntezy, bez technicznego wyliczania deklinacji i koniugacji w aspekcie poszczególnych ujęć gramatykopisarzy badanego okresu (por. realizację tego zagadnienia przez Z. Zagórskiego ${ }^{3}$ ).

3 Z. Zagórski, 1981, Studia nad rozwojem językoznawstwa polskiego od końca XVIII wieku do roku 1918 (ze szczególnym uwzględnieniem Wielkopolski), Warszawa-Poznań: Wydawnictwo Naukowe PWN. 
Na pozytywny odbiór rozprawy A. Czelakowskiej nie wpływają uchybienia, które wkradły się zapewne podczas redakcyjnego doprecyzowywania materiału (generalnie opracowanego bardzo starannie). Zwykle są to techniczne niedopatrzenia, jak np. niepotrzebne powtarzanie tych samych cytatów z tekstów źródłowych, nawet w bardzo bliskim sąsiedztwie (np. s. 86, 103, 94, 104) lub z rzadka niedostateczna ich weryfikacja (np. s. 97). W przedstawionej bibliografii autorka zamieściła tylko jedną pracę S. Agrella: Przedrostki postaciowe czasowników polskich (1918), brak natomiast pozycji: Aspektänderung und Aktionsartbildung beim polnischen Zeitworte (1908, Lund: Ohlsson), na którą również się powołuje, np. na s. 140 (por. s. 147). Nie do końca jasny wydaje się też termin wyrazy bezpośrednio pokrewne użyty na s. 79 w odniesieniu i do derywatów, i do form deklinacyjnych rzeczowników, a bezpośrednio nawiązujący do budowy morfologicznej wyrazów ${ }^{4}$.

Poza tym w kilku miejscach należałoby poprawić inne pomyłki, dla przykładu: na s. 148 autorka wymienia czasownik ochłodzić jako czasownik dokonany, następnie omyłkowo wymienia go również w grupie czasowników niedokonanych; na s. 213 zapisano: „których tematy są zakończone na spółgłoskę - $a$ ”; w zdaniu na s. 152: „Stosunkowo najrzadziej przyjmowano, że formy trybu [rozkazującego - ALK] muszą mieć syntetyczne wykładniki formalne, a więc przysługuje on tylko 2 os. lp. oraz 2 i 3 os. lm." należy skorygować zapis dotyczący form syntetycznych w lm. na: 1 i 2 os. 1m.; podobnie na s. 175: „Różnica w odmianie rzeczowników twardo- i miękkotematowych rodzaju «nijakiego» ${ }^{5}$ była tu widoczna w mianowniku i dopełniaczu liczby pojedynczej. W mianowniku twardotematowe miały mieć końcówkę -i (skarby, matki), miękkotematowe zaś -e [...]” należy poprawić informację o liczbie na: w mianowniku i dopełniaczu liczby mnogiej; na s. 179: „Za główną zasadę podziału dek linacji męskiej (o zakończeniach na spółgłoski lub samogłoski $e, o, e)$ i zarazem kryterium jej podziału na dwa wzory uznał [Suchecki - ALK] postać «przegubu trzona» [...]” powinna być dopre-

4 „Autor [H. Gaertner - ALK] rozpatrywał oboczności różniące rdzenie, które z jednej strony mają to samo znaczenie, z drugiej - «są do siebie podobne», a w wypadku występowania większych różnic (brat - bracie, mruk - mruczek) taką samą zmianę można dostrzec w wyrazach bezpośrednio pokrewnych (kat-kacie, wnuk-wnuczek)" (s. 79).

5 Według terminologii J. Mrozińskiego (1822/1986) „rodzaj nijaki” to odpowiednik współczesnego terminu niemęskoosobowy dla oddania rodzaju rzeczowników w liczbie mnogiej. 
cyzowana informacja dotycząca deklinacji (wg ujęcia H. Sucheckiego (1848)) na: deklinacji męsko-nijakiej.

Najwięcej niedomówień wprowadza informacja podana przez autorkę w przypisie 6 na s. 170: „W opisie stosuję zwykle terminologię używaną przez autorów analizowanych przeze mnie podręczników. Choć stosowane do dziś terminy wprowadził już Kopczyński, to Szumski posługiwał się łacińskimi, zaś np. Jakubowicz i Mroziński określeniami «drugi, trzeci przypadek» kolejność ich była zgodna ze współcześnie przyjętą [wyróżn. - ALK]". W celu uniknięcia późniejszych nieporozumień, wskazany fragment warto by skorygować na: ówcześnie przyjętą, bądź zastosować bardziej szczegółowe omówienie, np.: w gramatykach owego okresu układ przypadków nie był identyczny ze współczesnym, ponieważ wołacz umieszczano po bierniku, a nie na końcu paradygmatu. Dalej autorka oczywiście poprawnie posługuje się opisem przypadków gramatycznych, uwzględniając ową różnicę w kolejności przypadków w stosunku do gramatyk współczesnych, np.: ,(pierwszy i piąty przypadek $1 \mathrm{~m}$.) (M. i W.)”, ,, przypadku piątym (W.) i siódmym (Ms.)" (s. 171 i podobnie na następnych).

W rozdz. IV.4.3.3. w opisie trybu rozkazującego warto byłoby posługiwać się bardziej rozszerzoną specyfikacją gramatyczną, nieograniczającą się tylko do kategorii osoby, ale podawać również liczbę gramatyczną w celu uniknięcia niejasności przy wywodach dotyczących form imperatiwu w 1 os., zwłaszcza na s. 153, gdzie autorka omawia analityczne formy rozkaźnika, np.: w pierwszym akapicie lepiej by było zapisać bardziej precyzyjną informację: 1 os. lp. oraz 3 os. obu liczb (autorka pisze o formach złożonych w „1 i 3 os. trybu rozkazującego”). W drugim akapicie w zdaniu: „tryb rozkazujący ma formę opisową z niech dla 3 os. lp. i lm., złożoną z 3 os. czasu teraźniejszego koniugowanego czasownika i 2 os. trybu rozkazującego «słowa posiłkowego» niechać" warto zmienić szyk wskazanych elementów, tym bardziej że choćby w gramatyce I. Steina i R. Zawilińskiego, na którą m.in. autorka się powołuje, wymieniono składowe elementy konstrukcji opisowej rozkaźnika w szyku rzeczywistym. Poza tym, rozpatrując gramatyki XX-wieczne, nie tylko Z. Klemensiewicz (1939) wspominał o możliwości tworzenia opisowych form trybu rozkazującego w 1 os. $1 p .{ }^{6}$, ale wcześniej m.in. I. Stein

6 „Klemensiewicz jako jedyny przyjmował, że formy opisowe, «dwuwyrazowe», pojawiają się nie tylko dla 3 os., ale że przytrafiają się, choć bardzo rzadko, także dla 1 os. (1939: 124)" (s. 153). Poza tym tu również powinno się zapisać precyzyjniej: 1 os. lp. 
i R. Zawiliński: „Czasami zastępujemy w ten sposób [tworząc konstrukcję opisową - ALK] 1 os. 1. p., np. niech zginę! Niech zapomnię prawice ręki swojej." (cytat podaję za wyd. drugim Gramatyki... (1920: 126)). Ponadto ci sami autorzy wspominają o archaicznych formach prostych w 3 os. 1p. i wymieniają te funkcjonujące do dziś w spetryfikowanych frazach (1920: 126, podobnie wcześniej np. J. Muczkowski (1836: 232)), co niejako uzupełnia podaną przez autorkę na s. 153 informację pochodzącą z gramatyki J. Łosia (1927), który wskazywał odejście od niejednoznacznej homonimii 2 i 3 os. rozkaźnika jako powód dla tworzenia konstrukcji opisowych dla 3 os.

Wynotowane przykładowo usterki niewychwycone w korekcie nie wpływają na pozytywny odbiór całości. Książka stanowi solidne studium wiedzy na temat opisów fleksyjnych w gramatykach polskich okresu 1817-1939. Analiza przeprowadzona jest na szerokim tle prac językoznawczych tego okresu, jak i tych, które poza te ramy wykraczają. Dzięki temu opis jest czytelny, a wnioski rzetelnie przedstawione i niezawieszone w próżni historycznej opisu języka. Dużym walorem są też zwięzłe - zwykle ujęte w punkty - podsumowania podrozdziałów, co w sposób systematyczny zbiera we wnioski końcowe rozważania materiałowe z danej całostki w obrębie poszczególnych rozdziałów.

O wartości książki A. Czelakowskiej decydują - oprócz ścisłości merytorycznej, klarownego wywodu i swobody w poruszaniu się w tematyce stosunek autorki do opisywanego materiału badawczego. Jest on niezwykle wyważony, autorka nie krytykuje teorii, które należą jeszcze do okresu początkowego myśli językoznawczej - często są naiwne, nieścisłe. Stanowią one przecież historyczną dokumentację przemian i ewolucji zachodzących w świadomości językowej - i jako takie są przez autorkę postrzegane. Oczywiście z poziomu dzisiejszego językoznawstwa łatwo krytycznie ocenić i przekreślić dawne teorie, łatwo też znaleźć w nich słabe punkty, co A. Czelakowska czyni z trafnością i doskonałym umiejscowieniem ich na mapie dawnych poglądów. Omawiając gramatyki najróżniejszego pokroju - te amatorskie i intuicyjne, te sięgające po zdobycze europejskiej myśli lingwistycznej, jak i te będące świadectwem nurtu szeroko pojmowanej ochrony polszczyzny, daje rzeczowy, pozbawiony zbędnej retoryki wywód. To kolejna istotna wartość omawianej rozprawy: stanowi bogate, poprawne merytorycznie i niewątpliwie bardzo ciekawe studium opisów fleksyjnych (lub szerzej obraz kształtowania się nauki o wyrazie i fleksji) w gramatykach polskich lat 
1817-1939, a co za tym idzie, utrwala pewien etap w historii rozwoju badań lingwistycznych, jak się wydaje - prawie już zapomniany w swym szczegółowym wymiarze (głównie w odniesieniu do prac wcześniejszych z omawianego okresu), a przecież, jak zaznacza autorka: „zbadany materiał dowodzi, że wiele interesujących refleksji o języku pojawiło się już w okresie «językoznawstwa przednaukowego», kiedy właściwej nauki o języku, tworzonej na aktualnej podbudowie teoretycznej oraz opartej na badaniach materiałowych, w zasadzie nie było. Kilka rozwiązań przyjętych w gramatykach amatorskich stało się punktem wyjścia w okresie językoznawstwa naukowego i przetrwało w tradycji gramatycznej” (s. 228).

Anetta Luto-Kamińska Toruń, Instytut Badań Literackich PAN 
